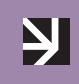

Hanna Chorell

Laulajan kehon queer-potentiaali Liediä Barthesin kanssa 
The Queer Potential of the Singer's Body. Singing Lieder with Barthes

In this article I show how the conventions of German Lieder performance aim to hide the singer's corporeality. The current culture of Western classical singing, dividing singers into gendered voice types is the result of a long process spanning centuries. This gendering is repeated in performance conventions and in the songs themselves, which reflect and repeat the binary gender system and heteronormativity of Western culture and societies. As an example of the German culture of Lieder performance I use baritone Dietrich Fischer-Dieskau's performing, singing and thinking. His still influential style of singing privileges the communication of text and its meanings as the main purpose of the singer's performance. This, combined with the tendency of hiding the voice's bodily origin, repeats the privileging of transcendence over immanence, mind over body, and masculine over feminine in Western culture and thought.

The theoretical framework of this article is in Judith Butler's thinking and Roland Barthes' music essays. After tracing and analysing gender performativity in Lieder performance conventions, I argue and demonstrate that through the employment of Roland Barthes' concepts of singing - phenosong, genosong and the grain of the voice - a singer can perform differently. These concepts give a singer tools to rethink singing and use the body as a way to dissolve and unravel the gendered norms of song performance. Barthesian singing becomes thus a queer space for all bodies, genders and desires. 


\title{
Laulajan kehon queer-potentiaali
}

\author{
Liediä Barthesin kanssa
}

\author{
Hanna Chorell
}

Keho, sen liha, luut, limakalvot ja nesteet ovat laulajan instrumentti ja maailmassa olo. Keho on useimmiten sukupuolitettu viimeistään syntymässä, ja siihen kohdistuu tästä juontuvia odotuksia, normeja ja paineita, jotka muokkaavat sitä. Laulajan työssä sukupuoli on koko ajan läsnä, sillä laulaja on länsimaisen klassisen laulun kulttuurissa sukupuolitettu äänityypin kautta, eikä laulaja voi piilottaa kehoaan soittimen taakse. Tässä artikkelissa tarkastelen, minkälaisia sukupuolittuneita käytäntöjä lied-musiikin esittämisen traditiossa on ja esittelen tavan, jolla niitä on mahdollista haastaa ja purkaa. ${ }^{1}$

Artikkelin teoreettinen viitekehys on Judith Butlerin queer-teoriassa ja Roland Barthesin musiikkiesseissä. Tarkastelen niiden avulla laulamisen ruumiillisuutta ja sukupuolen esityksiä, jotka ymmärrän Butlerin (2006 [1990]) mukaisesti sekä tiedostettuina että tiedostamattomina toistotekoina. Queerillä tarkoitan tässä artikkelissa biologisen ja sosiaalisen sukupuolen sekä seksuaalisen halun keskinäisten suhteiden ja katkosten esille nostamista (Jagose 1996, 3), mutta myös sukupuolen ja seksuaalisuuden moninaisuutta ja yhdenvertaisuutta vaalivia tiloja ja niiden etsimistä lied-laulamisesta (vrt. Välimäki 2015, 10).

Aloitan laulamisen sukupuoliesitysten tarkastelun jäljittämällä, minkälainen on liedin esittämiskäytännön kehosuhde ja mitä se tarkoittaa laulajan näkökulmasta. Klassinen musiikki on länsimaisen yhteiskunnan osana heteronormatiivisen ajattelun ja binäärisen sukupuolijärjestelmän lävistämä. Niiden vaikutus näkyy esittämiskäytännöissä, lied-runoudessa ja siinä kuinka esiintyjien sukupuolittuneisiin kehoihin suhtaudutaan.

1 Lämmin kiitos Laura Wahlforsille monista keskusteluista, jotka johtivat tämän artikkelin valaiseville ja sopiville sivuraiteille. Kiitos monista hyödyllisistä kommenteista myös Anne Kauppalalle ja Päivi Järviölle sekä DocMus-tohtorikoulun musiikin esittämisen seminaarilaisille. 
Kehosuhdetta pohdittuani siirryn Roland Barthesin lauluajatteluun etenkin esseen "The Grain of the Voice" ["Le grain de la voix"] avulla (Barthes 1985a [1972]). Esitän, että Barthesin laulukäsitteiden hyödyntäminen avaa oven patriarkaalisia normeja ja binääristä sukupuolijärjestelmää haastavaan queeriin lied-laulamiseen. Havainnollistan laulamisen sukupuoliperformansseja artikkelin lopussa lauluesimerkillä. Samalla osoitan, kuinka Barthesin laulukäsitteiden avulla liedin esittämistä voi ajatella ja toteuttaa toisin. Tutkimustekstien ja laulajien kuuntelemisen lisäksi hyödynnän omaa laulun ammattilaisen ja esiintyvän taiteilijan kokemustani.

Käsittelen tässä ensisijaisesti saksalaista 1800-luvun liediä ja sen saksalaista esittämisen traditiota etenkin baritoni Dietrich Fischer-Dieskaun laulamisen ja tekstien avulla. Sivuan oopperaa vertailukohtana klassisen laulun kulttuurissa, mutten syvenny siihen. Rajaan artikkelin ulkopuolelle sellaiset lied-lauluun ja esittämiseen liittyvät seikat, jotka eivät liity ääneen tai kehonkieleen, kuten konserttipaikan tai laulajan pukeutumisen. Myös pianistin ja laulajan välinen yhteistyö jää tällä kertaa käsittelyn ulkopuolelle, vaikka se on keskeinen osa liedin esittämistä.

Käyn artikkelissani kahdelle vähän käytetylle polulle laulamisen tutkimisessa. Näytän, kuinka laulaja voi työssään hyödyntää Barthesin klassikkokäsitteitä. Toisaalta käyttämäni queer-kehys tuo lied-tutkimukseen sellaisia näkökulmia, joista on vielä paljon ammennettavaa. Muun muassa Dame (2006 [1994]), Jarman-Ivens (2011) ja Välimäki (2005) ovat yhdistäneet Barthesin ajattelun queeriin lauluntutkimukseen, mutta oopperassa ja populaarimusiikissa. Queer-ajattelua ylipäätään on hyödynnetty lauluäänen, laulamisen ja soittamisen tutkimuksessa sekä klassisen että populaarimusiikin saralla, ja Wahlfors (2013) on tutkinut queer-näkökulmasta Barthesin ajattelun sovellusmahdollisuuksia muusikon työssä. ${ }^{2}$ Liedin esittämisen tutkimusta queer-näkökulmasta on jostain syystä kuitenkin vain vähän, varsinkin muusikoiden itsensä tekemänä. ${ }^{3}$ Tämän artikkelin tavoitteena on kuvata lied-laulun ruumiillisuuden mahdollisuuksia laulamisen sukupuolittuneiden normien purkamisessa. Fischer-dieskaulainen lied-laulun tulkintaihanne ei ole ainoa tapa, jolla liediä lauletaan. Sen vaikutus on kuitenkin niin huomattava, että koen mielekkääksi haastaa ja purkaa nimenomaan sitä toisenlaisella laulami-

2 Esim. Brett et al. 1994; Koestenbaum 1994; Dame 2006 [1994]; Peraino 2006; Bonenfant 2010; Jarman-Ivens 2011; Fast et al. 2019.

3 Esimerkkinä laulajan tekemästä queeristä lied-tutkimuksesta ks. kuitenkin Reece 2019. 
sella. Ruumiillisuuden ottaminen liedin esittämisen elementiksi paljastaa kehon häivyttämiseen pyrkivän normin ja siihen liittyviä valtasuhteita.

\title{
Liedin esittämisen kehollisuudesta ja sukupuolittuneisuudesta
}

\author{
"Liian kovaa" \\ "Oopperaan viritetty ääni, ei sovi liedin laulamiseen" \\ "Tarpeetonta käsien heiluttelua"
}

Edellä mainitut kommentit olen saanut kuulla tai lukea laulettuani julkisesti lied-musiikkia. Kommentit herättävät kysymyksiä. Mikä on liedin laulamiseen sopiva äänenvoimakkuus? Kyseinen esiintyminen oli isossa konserttisalissa, johon lyyrinen ääneni mahtui varsin hyvin. Entä mitä eroa on lied- ja oopperaäänillä? Miksei "oopperaan viritetyllä" äänellä voi laulaa liediä? Missä menee tarpeettoman ja tarpeellisen käsien heiluttelun raja? Kommentit kertovat kommentoijistaan ainakin sen, että heille on olemassa jonkinlainen lied-laulamisen ihanne. Kommentoinnilla viestitään normien olemassaoloa ja vahvistetaan niitä sulkemalla "vääränlainen" esittäminen normin ulkopuolelle. Mistä tällaiset ihanteet tai normit tulevat ja mitä ne kertovat lied-laulamisen kulttuurista?

Yksi saksalaisen lied-laulukulttuurin keskeisimmistä hahmoista on baritoni Dietrich Fischer-Dieskau (1925-2012). Hänen vaikutuksensa lied-laulun nykyiseen esittämisen käytäntöön on kiistaton, ja siksi nostan juuri hänen laulamisensa ja lauluajattelunsa tämän artikkelin esimerkiksi. Mittavan esiintyvän taiteilijan uran ja poikkeuksellisen laajan diskografian lisäksi Fischer-Dieskau myös kirjoitti liedistä ja laulamisesta (esim. 1971; 1981; 1984; 1985). Hänen laulutapansa oli sotienjälkeisessä Euroopassa uusi ja poikkeuksellinen. Sen tekstipainotteisuus rikkoi totuttua linjakkuutta ja laulullisuutta (ks. esim. Potter 2006, 546; Potter \& Sorrell 2012, 198; Barthes 1985a [1972]; Tunbridge 2010, 147-150). Hän lauloi uransa aikana laajasti myös oopperaa ja oratoriomusiikkia, mutta hänet yhdistetään etenkin saksalaisen liedin tulkitsemiseen. Hänen esiintymistään on nähtävissä lukuisina konserttitaltiointeina esimerkiksi YouTube-palvelussa. Aloitan katsomalla ja kuuntelemalla niitä. Kuvaan hänen kehonkieltään ja esiintymistään yleisesti. Sitten esittelen joitain hänen ajatuksiaan, yhdistän niitä 1800-luvun ilmiöihin ja toisaalta pohdin niiden sukupuolittuneisuutta. 
Fischer-Dieskaun 70-vuotissyntymäpäivän kunniaksi koottu dokumentti (Monsaingeon 1995) sisältää mielenkiintoista materiaalia koko hänen uransa ajalta. Lukuisten konserttitaltiointien lisäksi näytetään myös materiaalia levytyksistä ja harjoituksista. Fischer-Dieskau näyttäytyy monipuolisena taiteilijana, joka oli kuin kotonaan niin oopperan, oratorion kuin liedin parissa. Oopperalavalla hän on intensiivinen ja vakuuttava näyttelijä, jolla on selkeä diktio ja ketterä keho (esim. Monsaingeon 1995, 22:15). Myös harjoitellessaan Fischer-Dieskau liikkuu paljon ja käyttää käsiään. Kehonkielen kontrasti liedin esittämiseen on suuri. Flyygelin mutkassa sama ketterä ja suuri keho seisoo pääasiassa paikallaan. Hänen ylävartalonsa saattaa heilahtaa fraasin mukana tai kumartua ikään kuin hakemaan vauhtia alaviistosta, mutta käsiä hän ei juuri käytä eikä hän liiku paikaltaan (esim. Schubert: Winterreise, 1979). Toisin kuin hänen lähes liikkumaton vartalonsa, hänen kasvonsa ovat hyvin ilmeikkäät, mikä heijastuu lauluäänen monisävyisyytenä ja vivahteikkuutena.

Fischer-Dieskau kirjoittaa liedin tulkitsemisesta kirjassaan Töne sprechen, Worte klingen. Zur Geschichte und Interpretation des Gesangs (1985, 461-477). Luku toistaa ja täydentää kuvaa, jonka konserttitaltioinneista saa. Hän korostaa valmistautumisen, taustatyön ja ajattelun roolia laulamisessa. Laulumusiikki ei ole merkityksetöntä viihdettä, eikä pelkkä kaunis ääni puhuttele. Lied-musiikki on vastakohta viihteelle ja yleiselle passiivisuudelle. Hänen mukaansa tällaisen esityksen kuunteleminen kohottaa kuulijaa ("Steigerung"), sillä kuunteleminen osallistuttaa ja näin paljastaa kuulijalle häntä itseään koskevaa tietoa. Tärkeintä Fischer-Dieskaulle on kuitenkin tasapaino musiikin ja tekstin välillä, niiden yhtenäisyys ja samanarvoisuus. Hänen mukaansa tekstiä määrittää pääasiassa rationaalinen modaliteetti ja säveliä emotionaalinen. (Fischer-Dieskau 1985, 466-469.)

Fischer-Dieskaun mukaan laulutaide ei voi olla abstraktia, sillä se on aina sidottu laulajan instrumenttiin, elävään ja sykkivään kehoon, joka kuuluu laulajan Minälle ("Ich") (1985, 469). Tulkinnassa ei tule käyttää fyysistä liikehdintää tai eleitä, sillä liedissä tapahtumapaikkana on laulajan kasvot. Erotuksena oopperasta, jossa laulaja esittää yhtä roolia koko illan, lied-resitaalissa laulajan on esitettävä, ruumiillistettava ("verkörpern") ohjelman jokaisen laulun puhuja. (Ibid., 467.) Kun kerran kaikenlaista fyysistä liikehdintää on vältettävä, jää fischer-dieskaulaisen liedlaulajan työkaluksi äänellä ilmaisu. Lied-laulun dynaaminen rikkaus perustuu Fischer-Dieskaun (ibid.) mukaan hienovaraisiin vaihteluihin, toisin kuin ooppera. Dokumentissakin (Monsaigneon 1995, 1.28:00) hän 
toteaa, että lied on oopperaa vaikeampi laji, sillä lied vaatii oopperaa enemmän herkkyyttä tekstin tulkintamahdollisuuksille.

Fischer-Dieskau $(1985,467)$ luettelee esimerkinomaisesti Schubertin laulutuotannon nais- ja mieshahmoja. Naisiksi hän listaa muun muassa onnettomia, kuolleita tai eksotisoituja tyttöjä ja naisia (Mignon, Gretchen, Thekla, Ellen, Suleika). Maskuliinisia hahmoja ovat muun muassa harpunsoittaja, Ganymed, Prometheus, mylläri, haudankaivaja ja vaeltaja. Kaikkien hahmojen tulee Fischer-Dieskaun mukaan olla selkeitä ja siksi henkilökohtaisia. (Ibid.) Hän ei sano suoraan, että on miesten tai naisten lauluja, mutta valtavasta lied-levytysten määrästä huolimatta hän ei ole levyttänyt keskeisestä lied-ohjelmistosta esimerkiksi Schumannin Frauenliebe und -lebeniä, Schubertin, Schumannin tai Wolfin Mignon-lauluja, Schubertin lauluja "Gretchen am Spinnrade" tai "Die junge Nonne". Wolfin italialaisen ja espanjalaisen laulukirjan levytykset hän on tehnyt sopraano Elisabeth Schwarzkopfin kanssa jakaen laulut miesten ja naisten lauluiksi. ${ }^{4}$

Fischer-Dieskaun ajattelusta paljastuu kahtiajakoja - muun muassa teksti-musiikki, rationaalinen-emotionaalinen, minä-keho, mies-nainen, taide-viihde - jotka heijastavat hänen aikaansa ja paikkaansa, mutta myös länsimaisen ajattelun platonilaisia juuria ja kartesiolaista perinnettä (ks. esim. Cavarero 2005 [2003], 42-46). Samassa traditiossa rationaalinen ja subjektius on katsottu maskuliiniseksi ja vastaavasti emotionaalisuus ja ruumiillisuus feminiiniseksi. Fischer-Dieskau tulee siis sanoneeksi, että teksti on rationaalisuudessaan maskuliinista ja musiikki emotionaalisuudessaan feminiinistä.

Tekstin ja musiikin suhde vaikuttaa keskeisesti liedin merkityksiin ja laulajan tulkintaan. Saksalaisen 1800-luvun lied-ohjelmiston tyyli mahdollistaa laulajalle yleisöön välittyvän tekstintuoton. Lauluissa on harvoin diktion selkeyttä haittaavia musiikillisia ratkaisuja, kuten ääriääniä, raskasta pianotekstuuria tai runsasta kuviointia. Tämä ohjaa laulajaa keskittymään tekstiin ja sen ilmaisuun, tai Fischer-Dieskaun (ks. yllä) sanoin olemaan herkempi nimenomaan tekstin tulkintamahdollisuuksille. Fischer-Dieskaun ohje olla liikuttamatta kehoa laulaessa häivyttää laulajan materiaalista ruumiillisuutta ja suuntaa huomion pois laulajan kehosta. Tällainen ohjeistus niin ikään korostaa liediä sanojen ja merkitysten taiteena. Tästä tekstipainotteisuudesta seuraa, että laulajan immanentti

${ }^{4}$ Kävin läpi Fischer-Dieskaun levytykset Schubertin, Schumannin ja Wolfin lauluista discogs.com-sivuston tietokannasta. Näiden laulujen pois jättäminen ei välttämättä kerro Fischer-Dieskaun ehdottomuudesta, vaan voi johtua myös esimerkiksi levy-yhtiöstä. 
ruumis siirtyy taustalle teoksen välittämiseen ja kuulijan kohottamiseen tähtäävän transsendentin merkityksenmuodostuksen tieltä. FischerDieskau $(1985,466)$ esittää omastakin laulukoulutuksestani tutun näkemyksen, että pelkkä kaunis ääni ei puhuttele tulkinnallisesti vaan äänen täytyy palvella itse teoksen välittämistä. Hän ei vähättele äänen voimaa, mutta valjastaa sen merkitysten välittämisen käyttöön. Toisin sanoen feminiinisiksi mielletyt (kaunis) ääni, ruumiillisuus ja musiikki ovat alisteisessa asemassa itse teoksen kokonaisuuteen ja sen merkityksiin nähden. Lied näyttäytyy siis rationaalisen tulkitsija-laulajan transsendenttina toimintana, joka sijoittuu kehon välityksellä hieman paradoksaalisesti kehon ulkopuolelle. Liedin fischer-dieskaulainen tulkintaihanne pyrkii häivyttämään laulajan ruumiillisuutta keskittymällä tekstilähtöiseen, (maskuliinis-)rationaaliseen tulkitsemiseen. ${ }^{5}$

Fischer-dieskaulaisen esityskonvention pyrkimys musiikin ja tekstin tasapainon löytämiseen jää siis aina saavuttamatta. Näin esitettynä liedissä teksti edeltää musiikkia ja on siksi aina ensisijainen. Henkilökohtaisuus, laulajan Minän tuominen laulamiseen, vaikuttaa olevan ennen kaikkea transsendentilla tasolla tapahtuva merkityksenannon prosessi, jonka pääosassa on analyyttinen valmistautuminen. Tuloksena saadaan merkitysten kommunikointia, jossa laulajan materiaalinen ruumis ja ääni itsessään saavat vain välinearvon. Keholla laulaen välitetään tekstin merkityksiä, jotka ovat ensisijaisia itse laulamiseen, ääneen ja kehoon nähden. Kaikki laulajan toiminta, joka vetää huomion laulajan kehoon, häiritsee. Esimerkiksi "käsien heiluttelu", josta minullekin on huomautettu, on tällaista kehoa esille tuovaa häiritsevyyttä. Myös kaikenlainen ääneen huomion vievä, kuten "pelkkä kaunis ääni" tai portamentot, häiritsee itse teoksen ja merkitysten välittämistä. ${ }^{6}$ Näin musiikki ja ääni alistetaan tekstin merkityksille eikä todellista tasapainoa musiikin ja tekstin välillä saavuteta.

Fischer-Dieskau ei keksinyt suhteellista fyysistä liikkumattomuutta lied-konsertissa. Sen juuret ovat liedin siirtymisessä 1800-luvun porvariskodeista konserttisaleihin ja amatööreiltä ammattilaisille. Konserttisali tilana oli ja on edelleen pääasiassa soitinmusiikille omistettu. Konserttisalista puuttuvat oopperan ja teatteritilan luomat mielleyhtymät

${ }_{5}^{5}$ Vrt. Goehrin $(1998,134)$ jako teoksen täydelliseen esittämiseen, jossa fokus on teoksessa (apolloninen) ja täydelliseen musikaaliseen esittämiseen, jossa fokus on esittäjässä (dionyysinen). Teoskeskeisyydessä esiintyjä on väline, jonka tähtäimenä on toistaa saavuttamaton teoksen ideaali. Ks. myös Leech-Wilkinson 2020.

${ }^{6}$ Potter $(2006,546)$ jäljittää portamenton lähes täydellisen häviämisen lied-laulusta juuri Fischer-Dieskauhun. 
keinotekoisuuteen ja ruumiillisuuteen. Näin konserttisali tilana nosti liedin arvoa taidemuotona, ja siten sen esittäminen sopi myös naisille. Kaikki teatraalisuuteen viittaava herätti kuitenkin paheksuntaa, joten hyvää naislaulajan lied-esitystä kuvattiin esimerkiksi hillityksi tai ylvääksi ja esittäjää kuninkaalliseksi tai marmoripatsasmaiseksi. (Borchard 2020, 145-146; Cole 2020, 234-235.) Ruumiillisuuden häivyttäminen on (nais)sukupuolen ja feminiinisyyden häivyttämistä (ks. esim. McClary 2002 [1991], 68). Jäänne tästä 1800-luvun esityskäytännöstä elää vielä, sillä onhan lied-resitaalin kuva edelleen lähes paikallaan flyygelin mutkassa seisova laulaja.

Lawrence Kramer $(2011,157)$ kuvaa Fischer-Dieskaun toiminnastakin tuttua lied-laulumaailman vallitsevaa esittämiskonventiota toteamalla, että naislaulajat voivat laulaa kaikenlaisia lauluja, mutta mieslaulajat laulavat pääasiassa vain lauluja, joissa on miespuhuja. Tällainen käytäntö vahvistaa ajatusta, jossa mies on universaali subjekti, mutta nainen sukupuoli. Mies laulamassa naisena on joko koomista tai miehen universaalia subjektiviteettiä uhkaavaa (ibid.). Naislaulaja voi laulaa "miehenä", mutta se on aina mimeettistä, esittämistä. Mieslaulajan ei tarvitse esittää, koska hän todella on eikä vain esitä olevansa. 1800-luvulla liedin esityskäytännössä sukupuolella ei ollut merkitystä laulujen esittämisen kannalta, kunhan esiintyminen oli hillittyä. Laulujen jakaminen sukupuolen mukaan onkin sotien jälkeisen ajan keksintö (Borchard 2020, 146).

Lied-tekstien naishahmot ovat aikansa kuva ja usein miesrunoilijoiden fantasia siitä, mitä nainen ja naisen elämä on. Maskuliinisen halun kohteena ja yhteiskunnan Toisena nainen on Lorelein tai Suleikan kaltaisina eksotisoituina naishahmoina. Adalbert von Chamisson teksti Robert Schumannin Frauenliebe und -leben -laulusarjaan on malliesimerkki porvarillisen yhteiskunnan naisihanteesta. Naisen elämä typistyy miehen odottamiseksi, miehen palvelemiseksi ja äitiydeksi. 1700-1800-luvuilla naisen asema yhteiskunnassa olikin heikko. On siis johdonmukaista, että se tuotti tekstejä, joissa nainen on olemassa vain suhteessa mieheen.

Frauenliebe und -lebenin esittäminen nykypäivänä nostaa esiin kysymyksen kontekstista ja taiteen elävyydestä. Jos laulajan ja pianistin tulee eläytyä 1800-luvun maailmaan ja esittää laulut tosissaan, kuten esimerkiksi pianisti Richard Miller ehdottaa Schumannin laulujen esittämistä koskevassa kirjassaan $(1999,87)$, lauluista tulee museoesineitä, joilla on toki oma arvonsa, mutta voiko silloin puhua taiteen elävyydestä tai relevanttiudesta nykykuulijalle? Äärimmillään niiden esittämisen voi tulkita konservatiivisen ja misogyynisen naiskuvan representaatioksi ja toistoteoksi, jolla vahvistetaan binääristä sukupuolijärjestelmää ja siihen liittyviä 
valtasuhteita asettamalla kuuntelija (ja laulaja) subjektiksi tällaiseen järjestelmään (Kramer 1995, 144). ${ }^{7}$

Romantiikan ajan lied-ohjelmiston miehet laulavat myös esimerkiksi rakkaudesta tai luonnosta, mutta tekstien miespuhujat ovat olemassa itsenään eivätkä vain suhteessa naiseen. Saavuttamatonta ja määrittelemätöntä etsivä vaeltaja on romantiikan ajan ehkä ikonisin (mies)hahmo. Vaeltajarunous kuvaa matkaa itsensä löytämiseen ja sisäisiin maailmoihin esimerkiksi erilaisin luontometaforin (ks. esim. Youens 2013 [1991],15). Niin sukupuolitetut persoonapronomit, käytäntö kuin Fischer-Dieskau määrittävät vaeltajan mieheksi, vaikkei ole olemassa mitään syytä, miksei nainen - tai ihminen sukupuolesta riippumatta - voisi vaeltaa itseensä ja kokea vaeltajahahmojen kuvaamia tunteita.

Ammattimaisesti liediä esittävät nykypäivänä pääasiassa menestyneet oopperalaulajat, sillä lied-konsertti on klassisen laulumusiikin marginaalissa oopperaan verrattuna ja vain nimekkäät oopperalaulajat täyttävät konserttisaleja lied-ohjelmistolla. Pääasiassa liediin profiloituneita laulun ammattilaisia on maailmassa vain kourallinen (tällä hetkellä esimerkiksi Christian Gerhaher ja Ian Bostridge). Liediä lauletaan siis oopperalauluun koulutetulla äänellä, isoissa konserttisalessa ja ison konserttiflyygelin äänen kera. Liedin esittämisessä on tultu kauas Schubertin itsensä laulamasta ja soittamasta Winterreisesta tai porvariskotien (nais)amatöörisoittajien ja -laulajien harrastuksesta.

Voi olla, että saamani kommentti liian kovaa laulamisesta piti paikkansa ja kuuntelijan korviin sattui. Voi myös olla, että käyttämäni dynaaminen skaala ei mahtunut kyseisen kuuntelijan normiin lied-laulamisen hienovaraisuudesta. Toisen kuulijan arvio ääneni oopperaviritteisyydestä pitää varmasti paikkansa, sillä laulan pääasiassa oopperaa. Aivan toinen asia on, miksei "oopperaäänellä" voisi laulaa liediä. Eikö minulla taiteilijana ja laulamisen ammattilaisena ole vapaus laulaa juuri niin kuin haluan? Mitä ylipäätään tarkoittaa oopperaan viritetty ääni? Myös FischerDieskau käytti laajaa dynaamista skaalaa laulaessaan ja lauloi mittavan oopperauran, eikä hänen ääntään kukaan moiti oopperaan viritetyksi. Mikä siis tekee minun äänestäni (tai vastaavasti kenen tahansa oopperalaulajan äänestä) tämän yhden kuulijan mukaan sopimattoman liedin laulamiseen? Oopperaa taidemuotona luonnehtii tietynlainen kohtuuttomuus ja ruumiillinen äänijuhla, jolla ei ole juurikaan tekemistä liedin tekstilähtöisen merkityksenmuodostuksen kanssa. Ehkäpä "oopperaan viritetty" ääneni oli sitä kommentoineelle kuulijalle rajan ylitys vallitse-

\footnotetext{
7 Ks. toisaalta Reece (2019, 33-97), joka esittää vaihtoehtoisia luentoja laulusarjalle.
} 
van lied-kulttuurin hienovaraisuuden vaatimuksesta tekstin merkityksiä uhkaavaan ruumiillisuuteen?

\section{Barthes ja laulaminen}

Jos fischer-dieskaulaisen ideaalin mukainen lied-laulu on transsendenttia ja ruumiillisuuden unohtavaa, mitä on tehtävä laulamisessa kuitenkin kokonaisvaltaisesti läsnä olevalle ruumiille? Laulaminen on elävän kudoksen soimista, joten todellisuudessa ruumiillisuutta ei voi kokonaan häivyttää. Tekstin kommunikointia korostava Fischer-Dieskau tunnusti kehon olennaisuuden laulamisessa, mutta hänelle keho oli vain väline, joka tuli häivyttää kokonaiskuvasta. Lihallinen, sukupuolitettu keho tuottaa lauluäänen, joten se ei voi olla vaikuttamatta merkityksien muodostamiseen laulamisessa. Laulamisen merkityksenmuodostus ei siis voi olla kokonaan irti kehosta. Lied-laulun kiinnittyneisyys binääriseen sukupuolijärjestelmään ja heteroseksuaaliseen normiin sulkee ulkopuolelleen näihin normeihin sopimattomia ihmisiä ja kehoja. Roland Barthesin kanssa liediä ja laulamista on kuitenkin mahdollista ajatella toisin.

Barthesin äänen grain,${ }^{8}$ fenolaulu ja genolaulu ovat muodostuneet laulamisen ruumiillisuuden tutkimuksen klassikkokäsitteiksi. Yhdistettynä queer-ajatteluun niitä ovat käyttäneet esimerkiksi Jarman-Ivens (2011) ja Välimäki (2005) analysoidessaan normeja rikkovaa lauluääntä ja laulutapaa populaarimusiikissa. Wahlfors (2013) käyttää niitä vastaavasti oopperaäänen ja laulajamuusikon työn queer-kuuntelussa. Pyrin tällä artikkelilla täydentämään Barthesin ajattelua käyttävää queer-tutkimuskenttää vähemmän huomiota saaneen lied-laulun osalta. Esittelen käsitteitä ensin lyhyesti ja pohdin niitä laulajan kannalta. Sivuan laulajan ja kuuntelijan suhdetta tekijän kuolema -ajattelun kontekstissa. Pohdin myös, miten Barthesin käsitteet vaikuttavat laulamisen sukupuoliesityksiin ja mitä ruumiillisuuden tuominen laulamisen merkityksenmuodostuksen etualalle tarkoittaisi. Artikkelin lopussa annan käytännön esimerkin käsitteiden soveltamisesta laulajan työssä.

Esseessään "The Grain of the Voice" (1985a [1972]) Barthes määrittelee, mitä tarkoittaa äänen grainillä, sekä esittelee feno- ja genolaulun käsitteet. Näistä käsitteistä on kirjoitettu kattavasti (esim. Kauppala 2020; Wahlfors 2013, 57-96; Jarman-Ivens 2011; Dunsby 2009; Sivuoja-

8 Äänen grain on vaikeasti käännettävä termi, jolle ei ole kaikki merkityssisällöt kattavaa käännöstä, ks. Wahlfors 2013, 61 . 
Gunaratnam 2007; Välimäki 2005; Petersen 2001) eikä niiden syvällinen käsittely ole tämän artikkelin keskiössä. Barthesin omien tekstien lisäksi nojaan siis muun muassa edellä mainittuihin tutkimuksiin käsitteistä kirjoittaessani, mutten pyri tyhjentävään esitykseen. Ennemmin avaan tekstilläni tietä vaihtoehtoiseen tapaan ajatella laulamista ja sen merkityksiä laulajan näkökulmasta.

Barthes käyttää esimerkkeinään kahta baritonia, fenolaulusta Fischer-Dieskauta ja genolaulusta Charles Panzéraa (1896-1976). Fenolaulun Barthes määrittelee merkitysten, tunteiden ja kulttuurin kommunikoinniksi (1985a [1972], 270). Toisin sanoen kaikki kommunikointiin ja tulkintaan liittyvä laulajan toiminta on fenolaulua. Barthesin (ibid., 271) mukaan Fischer-Dieskau laulaa ekspressiivisesti ja dramatisoiden, muttei koskaan ylitä porvarillisen lied-laulukulttuurin rajoja. Fischer-Dieskaulle on tyypillistä, että vokaalit ovat hyvin staattisia eivätkä elä sävelen mukana (Sivuoja-Gunaratnam 2007, 57). Hän laulaa pyöreällä ja pehmeäsointisella äänellä, jossa ei erotu metallista yläsävelsarjaa. Hän välittää tulkintaansa ajoittain laulutekniikan ja legatolinjan kustannuksella, mikä diktion selkeyden lisäksi korostaa kommunikointihalua. Fenolaulu on siis laulutekstin merkityksiä lukitsevaa toimintaa. Laulaja voi päättää sanottavansa harjoitusvaiheessa tai vasta konserttitilanteessa, mutta joka tapauksessa tällainen laulaminen painottaa tekstin merkitysten välitystä laulamisen muiden elementtien ylitse.

Genolaulu on Barthesille tila, jossa merkitykset itävät kielen materiaalisuudesta (1985a [1972], 270). Laulamisen painopiste on merkitysten välittämisen sijaan kielen materiaalin eli äänteiden tuottamisessa sävelin. Laulaja asettuu äänellään ja laulavalla lihallaan merkitsijään, mutta ei tuota merkityksiä tai ilmaisua vaan aistimellista merkitsevyyttä [signifiance], jossa merkitsijän ja merkityn välinen yhteys hämärtyy (Wahlfors 2013, 58). Yksittäiset, kehossa soivat äänteet uhkaavat ja kumoavat sanojen merkityksiä ja saattavat ne liikkeeseen. Genolaulussa pysyviä merkityksiä ei ole. On vain laulajan äänteitä tuottava keho, joka kuuluu äänen grainin kautta. Genolaulun käytännön kuvausta hankaloittaa se, että genolaulua ei voi tuottaa suoraan, vaan se tapahtuu aina fenolaulun kautta (ks. esim. Wahlfors 2013, 61; Välimäki 2005, 384). Genolaulu on merkitysten ylijäämässä, joka on sanallistamisen ulottumattomissa. Sen tuottaminen tapahtuu ikään kuin tietynlaisen laulamisen sivutuotteena, jolloin se on kuitenkin paikallistettavissa (SivuojaGunaratnam 2007, 59).

Barthesin esimerkki genolaulusta on Charles Panzéra, joka laulaa soivalla ja metallisella äänellä. Barthes ihannoi Panzéran diktiota: kon- 
sonantit ovat keveitä, eivätkä ne koskaan katkaise lausumisen linjaa ja toimivat ainoastaan ponnahduslautoina "ihailtaville vokaaleille". Panzéra ei laulamisessaan uhraa legatoa eikä äänen sointia diktion selkeydelle. (Barthes 1985a, [1972], 272-273.) Jotta laulaja lukitsisi merkityksiä mahdollisimman vähän ja antaisi genolaululle mahdollisuuden syntyä, laulajan on pyrittävä sellaiseen laulutapaan, joka ei osoittele tai dramatisoi (Wahlfors 2013, 65). On vältettävä artikulaation ylikorostumista ja äänen tietoista tai tarkoituksellista värittämistä. Genolaulu ei kuitenkaan tarkoita tasaista, väritöntä, homogeenista tai merkityksetöntä laulua, vaan huomion kiinnittämistä äänen ja äänteiden kohtaamiseen lukittujen merkitysten välittämisen sijaan.

Barthesin mukaan äänen grain kuuluu, kun laulaja antaa äänteiden ja musiikin vaikuttaa toisiinsa. Grain on kitka musiikin ja kielen kohtauspinnassa (1985a [1972], 273). Omassa laulajankokemuksessani yhdistän grainin artikulaattoreilla ${ }^{9}$ tuotetun vokaalin ja "raakaääntä" tuottavan kehon vuorovaikutukseen. Vuorovaikutus on dynaamisempaa, kun keskityn äänen mahdollisimman vapaaseen ja soivaan tuottamiseen kommunikaation sijaan. Fenolaulussa grain ei kuulu, koska siinä ei ole kitkaa tuottavaa vuorovaikutusta. Laulajan etukäteen päättämä merkitys lukitsee musiikin, kehon ja kielen kommunikoimaan samaa asiaa, jolloin kitkaa aiheuttavaa liikettä ei ole. Genolaulussa merkitykset ovat vasta muotoutumassa, joten äänteen ja sävelen merkitysten liike tuottaa kitkaa ja hankausta niiden välille. Barthes ajattelee, että grain tuottaa kuulijalle laulajan kehon äänen (1985a [1972], 276). Kuitenkin ääni, jossa grain kuuluu, on persoonaton, vailla subjektia (ibid., 270), sillä kielen merkityksistä muodostuva subjekti purkautuu merkitsijä-merkitty-sidoksen purkautuessa. Barthes yhdistää subjektin mieleen ja kieleen, ei kehoon. Barthes tulee siis ohittaneeksi ruumiillisuuden subjektiuden ja ainutkertaisuuden lähteenä (Wahlfors 2013, 410).

Barthesin hämmentävä jako feno- ja genolauluun on tahallisen kärjistetty, utopistinen ja kehoa romantisoiva. Laulajan käytännössä feno- ja genolaulu toimivat yhdessä. (Wahlfors 2013, 62-63.). Feno- ja genolaulu ovat merkityksenmuodostuksen teoreettiset ääripäät, lukittu ja avoin. Ääripäitä on mahdoton saavuttaa, mutta niiden välillä on jatkumo, jolle kaikki laulaminen sijoittuu. Jatkumolla liikkuminen, feno- tai genolaulupainotteinen laulu, on mielestäni laulajan työssä täysin käyttökelpoinen työkalu, joka laajentaa laulajan ilmaisullisia mahdollisuuksia.

\footnotetext{
9 Artikulaatiossa käytettävät lihakset eli kieli ja ne kasvojen lihakset, jotka vaikuttavat suun ja suuontelon muotoon.
} 
Kaikessa laulamisessa on siis aineksia sekä feno- että genolaulusta. Yhden laulun aikana laulaja voi liikkua tai antaa laulamisensa liikkua jatkumolla merkitysten välittämisen ja lihallisuuden välillä. Näin on myös Barthesin laulajaesimerkkien kohdalla. Fischer-Dieskau osaa laulaa legatossa ja luistella soivalla äänellä konsonanttien yli. Vastaavasti Panzéra syyllistyy linjan katkomiseen konsonantteja korostamalla silloin tällöin. Barthes tuntuu kirjoittaessaan kuulevan idealisoidun version Panzéran laulusta ja jonkinlaisen huonon stereotypian Fischer-Dieskausta. Hän arveleekin, että lauluäänen totuus on olla hallusinoitu (1985a [1972], 272). Barthesin mukaan hänen kuvauksensa grainistä on abstrakti selvitys hänen omasta laulamisen kuuntelemisen nautinnostaan (ibid., 269).

Tiettyjen merkitysten välittämiseen keskittyvä fenolaulu sisältää genolaulua, sillä kommunikointiin tarvitaan sanat, jotka muodostuvat äänteistä ja lihastyöstä. Genolaulu taas on mahdollista vain fenolaulun kautta, ja se sisältää siis aina myös fenolaulua. Kukaan laulaja kehoineen ei elä yhteiskunnan tai vallitsevan kulttuurin diskursseista erillisenä, joten niiden ulkopuolelle ei voi päästä. Kehon soinnista ja äänteistä nousevat merkitysten idut ovat myös osa kulttuuria. Laulamisen merkityksiä muodostavat myös esimerkiksi laulutilanne ja laulettava ohjelmisto, joten puhdas vain merkitsevyyttä sisältävä genolaulu jää aina saavuttamattomaksi.

\section{Barthesilainen laulu ja sukupuolen esitykset}

Liedin esityskonventiossa laulajan ymmärretään esiintyvän resitaalissa omana itsenään (Binder 2020). Laulajan "itseys" lied-resitaalissa on sukupuolittunut subjektiasema, joka rakentuu ja tulee esitetyksi muun muassa laulajan lavapersoonan, äänityypin, kehon ja laulettavan ohjelmiston perusteella. Sukupuolen performatiivisuus on Judith Butlerin kirjassaan Gender Trouble (2006 [1990]) esittelemä ajatus. Butler kääntää käsityksen sukupuolesta biologian määrittämänä yhteiskuntasuhteena ympäri ja esittää, että yhteiskunnan ja kulttuurin sukupuoleen vaikuttaviin diskursseihin osallistuminen on sekä tietoisen että tiedostamattoman tasolla tapahtuva performatiivinen teko, jonka kautta sukupuolta tuotetaan. Sukupuoli ei näin ole pysyvä tai a priori ominaisuus vaan jatkuvan neuvottelun ja muutoksen alainen subjektiasema, jossa kulttuurin ja yhteiskunnan diskurssit vaikuttavat ihmisen identiteetteihin ja kehoon ja muokkaavat sitä. 
Myös laulaminen on sukupuolta tuottava toistoteko. Vallitsevan (laulu)kulttuurin ja yhteiskunnan normeista kumpuavien merkitysten toisto laulamalla peittää subjektin perimmäistä epävakautta (vrt. Butler 2006, 198). Näin tuotettu subjekti asettuu heteroseksuaaliseen matriisiin ja sen normeihin riippumatta laulajan todellisesta kokemuksesta omasta identiteetistään tai subjektistaan. Etenkin ilman kontekstia tällainen toistoteko vahvistaa myös nyky-yhteiskunnan sukupuoleen liittyviä konservatiivisia normeja. Normit muodostuvat merkityksistä, joita sanat ja ilmiöt saavat. Merkityksenmuodostuksen logiikan valinta eli valinta feno- ja genolaulun välillä näyttäytyykin poliittisena tekona, jolla voi joko vahvistaa tai heikentää normeja.

Laulajan koulutus, johon kuuluu klassisen laulutekniikan omaksuminen, muokkaa kehoa ja jakaa laulajat sukupuolittuneisiin äänityyppeihin. Kärjistettynä korkea, kevyt ja pieni ääni on feminiininen ja vastaavasti matala, raskas ja suuri maskuliininen. Näitä merkityksiä vahvistetaan ja toistetaan ohjelmistovalinnoilla, harjoituksissa ja esityksissä. Oopperalaulajan koulutus sisältää kuitenkin valtavan emansipatorisen potentiaalin. Naiselle on sallittua ja suotavaa tuottaa ääni, joka täyttää tilan ja vaatii kuuntelemaan (ks. Bull 2019, 132-154). Ristiriita tämän ja tyttöjen kasvatuksessa edelleen näkyvien kiltteys- ja huomaamattomuusvaatimusten välillä on ilmeinen. Toisaalta ristiriitaa aiheuttaa myös liedtekstien naiskuva. Koulutuksella rakennettu soiva ja tilan täyttävä ääni valjastetaan 1800-luvun porvarillisen naisihanteen toistamiseen, jolloin koulutetun äänen vapauttava potentiaali jää käyttämättä.

Myös musiikki sukupuolittaa laulajaa. Säveltäjät saattavat säveltää erilaista musiikkia runon mies- ja naispuhujille. Esimerkiksi Brahmsin laulun "Von ewiger Liebe" op. 43/1 miespuhujan Brahms panee toistuvin crescendoin ja fortein laulamaan kovaa täyteläisen pianotekstuurin päälle. ${ }^{10}$ Naispuhujaa Brahms taas laulattaa pääasiassa pianissimossa dolcesävyllä. Palaan tämän laulun sukupuoliperformansseihin ja barthesilaisen lauluajattelun mahdollisuuksiin sen suhteen artikkelin lopussa.

Laulaja esittää sukupuoltaan laulukulttuurissa tunnistettavilla merkeillä ja merkityksillä (Cusick 1999). Klassisen laulun kontekstissa näitä merkkejä ovat muun muassa äänen korkeus, väri ja voimakkuus sekä laulettavien tekstien merkitykset. Lauluäänen materiaaliset rajat rajoittavat sukupuolen esittämistä. Sopraano ei voi laulaa bassokorkeudelta, eikä kevyt ääni taivu jyrinään. On myös tyypillistä, että laulajat esittävät

${ }^{10}$ Kiitos tästä laulusta ja monista artikkelin aiheita sivuavista keskusteluista mezzosopraano Ann-Marie Heinolle. 
jonkun toisen säveltämää ja kirjoittamaa musiikkia, mikä osaltaan myös rajaa sukupuolen esittämisen mahdollisuuksia, sillä laulaja ei itse päätä säveltasoja tai tekstiä. Laulajan suhde tekstiin ja sen laulamiseen on siis sukupuolen esittämisen kannalta olennainen merkityksiä luova asia. Feno- ja genolaulun jatkumolla liikkuminen avaakin mahdollisuuden sukupuolirooleilla leikittelyyn ja niiden rajojen haastamiseen ja rikkomiseen.

Fenolaulussa laulaja päättää, mitä haluaa laululla sanoa, ja kommunikoi laulun valmistamistyössä lukittuja merkityksiä mahdollisimman selkeästi artikuloiden ja musiikillisesti ilmaisten. Näin tuotetaan laulun sukupuolittunut subjektiasema. Laulaja voi korostaa tekstin naispuhujan feminiinisyyttä tuomalla esiin tekstin sukupuolittavia tekijöitä. Myös esimerkiksi legaton, dynamiikan ja rytmin käsittelyn keinoin voi viestiä sukupuoliasemaa. Kukin laulaja käyttää itselleen tyypillisiä kommunikoinnin työkaluja mielikuvilla leikkimisestä äänen värien tietoiseen muokkaamiseen. Merkitysten kommunikointi sulkee pois muita mahdollisia merkityksiä, jolloin laulaja siis päättää kuulijan puolesta, mistä laulussa on kyse, ja asettuu näin tekijän asemaan.

Esseessään "La mort de l'Auteur" (1994 [1968]) [”Tekijän kuolema”] Barthes esittelee ajatuksensa, että tekstillä ei ole jumalankaltaisen Tekijän määräämää perimmäistä merkitystä. Tekijän auktoriteetin sijaan merkityksenmuodostuksen todellinen paikka on kirjoittamisen sijaan lukeminen. Moniulotteisen kirjoituksen kaikki tasot, kulttuurit, sitaatit ja merkitykset yhdistyvät kokonaiseksi tekstiksi vasta lukijassa, ei Tekijässä. Barthesille lukija ei ole henkilö vaan tila tai kenttä, jossa tekstin kaikki merkitykset tulevat yhteen. Tekstin yhtenäisyys ei siis kumpua sen alkuperästä vaan sen kohteesta. (Barthes 1994 [1968], 64.)

"Tekijän kuolema" -esseen kontekstissa laulajalla on kaksoisrooli. Säveltäjään ja runoilijaan nähden laulaja on lukijafunktiossa. Kuulijaan nähden laulajaa taas voi ajatella tekijänä, joka tarjoaa kuulijalle valmiin laulutulkinnan. Laulaja voi siis yhtä aikaa olla sekä tekijä että lukija. Predikoivassa ja subjektia vahvistavassa fenolaulussa laulajan rooli kuulijaan nähden on tekijän. Subjektin ja objektin rajaa häivyttävässä, merkityksiä avoimeksi jättävässä genolaulussa myös laulajan ja kuulijan raja hämärtyy. Näin muodostuu jatkuvassa liikkeessä olevien, muuttuvien merkitysten lukemisen kenttä, josta Barthes "Tekijän kuolema" -esseessään kirjoittaa (1994 [1968], 65).

Genolauluun pyrkivässä laulamisessa laulaja siis luopuu tekijyydestä ja antaa kuulijalle fenolaulua suuremman mahdollisuuden muodostaa merkitykset itse. Tekijyys merkityksien määrittelemisenä on heteronor- 
matiivisen sukupuolihierarkian kaltainen valta-asema, jonka fenolaulaja ottaa sekä kuulijaan että tekstiin ja musiikkiin nähden kommunikoidessaan merkityksiä. Cusick (2006 [1994], 70) esittää musikaalisuuden olevan seksuaalisuuden kaltainen tapa ilmaista ja toteuttaa intiimejä suhteita jakamalla, saamalla ja antamalla fyysistä nautintoa. Muusikon (ja musiikin kuuntelijan) suhde musiikkiin on siis fyysinen. Laulajalle musiikin fyysisyys on korostunutta, sillä laulaja on itse oma soittimensa ja laulajan musiikki tulee konkreettisesti kehon sisältä. Fenolaulupainotteisessa laulamisessa eli fischer-dieskaulaisessa lied-laulun konventiossa tämä fyysisyys on peittynyttä, sillä huomio on merkitysten välittämisessä. Cusickin ajattelua (2006 [1994], 72) jatkaen fenolaulu on valtasuhde, jossa laulaja asettuu hierarkiassa sekä musiikin että kuuntelijan yläpuolelle. Heteroseksuaalisen normin kaltaisesti fenolaulaja ottaa aktiivisen (maskuliinisen) roolin ja asettaa musiikin ja kuuntelijan passiivisiksi (feminiineiksi) vastaanottajiksi. Cusick kuvaa suhdettaan musiikista saamaansa nautintoon samankaltaisesti kuin Barthes kuvaa omaa grainin tuottamaa nautintoaan. Barthesille (1985a [1972], 276) grainin kuunteleminen on kahden kehon, muusikon ja kuulijan, välisen suhteen kuuntelemista. Grainin mahdollistavassa genolaulussa tämä suhde on tasa-arvoinen ja vastavuoroinen fenolaulumaisen merkitysten pakottamisen sijaan. Genolauluun pyrkivä laulu antaa musiikille tilaa tuottaa nautintoa, Cusickin sanoin "to do it" (2006 [1994], 76).

Barthesille (1985b [1976], 287) lied-laulu rakastuneen diskurssina ylittää sukupuolirajat, sillä rakkaus ei katso sukupuolta tai sosiaalista asemaa. Ymmärrän Barthesin puhuvan liedin potentiaalista rajojen kumoamiseen, sillä liediä voi laulaa myös rajoja vahvistavalla tavalla. Erityisesti genolauluun pyrkimisellä voi nostaa liedin esityskonventioon kadonneen kehon esille ja avata kielessä rakentuneen sukupuolijärjestelmän rajoja. Genolaululle avoimessa laulamisessa kielessä rakentuva laulajan subjekti purkautuu, kun merkityksenannolle olennainen merkitsijän ja merkityn välinen yhteys hämärtyy. Tällöin myös subjektin paikka sukupuolijärjestelmässä heikentyy ja samalla koko sukupuolijärjestelmä tulee kyseenalaistetuksi. Binääristä sukupuolijärjestelmää voi kyseenalaistaa myös fenolaulun keinoin, jolloin laulaminen voi olla dragin kaltaista sukupuoliroolien liioittelua, parodiointia tai niillä leikkimistä (vrt. Butler 2006 [1990], 186-189).

Laulu on kehollista osallistumista laulamisen kulttuuriin (Cusick 1999, 29). Genolaulu diskurssien tai kulttuurin vaikutteiden ulkopuolisena laulamisena on siis saavuttamaton utopia. Laulajan keho on yhtä lailla yhteiskunnan ja kulttuurin diskurssien muokkaama kuin ne merkitykset, 
joita fenolaulussa kommunikoidaan. Laulajan työssä ei siis ole mielekästä ajatella avoimuutta genolaululle yhteiskunnallisten tai kulttuuristen diskurssien ulkopuolelle pyrkimisenä, vaan niiden muokkaamisena fenolaulusta eriävällä toistamisella. Näin laulaja voi saattaa liikkeeseen, "queeriyttää" ja kyseenalaistaa esimerkiksi liedin kehollisuutta kaihtavaa esityskonventiota, sukupuolittuneiden persoonapronominien rajoja, oman äänensä ja kehonsa sukupuolittamista ja niihin liittyviä merkityksiä, tekstin tarjoamaa ihmiskuvaa tai merkityksenmuodostuksen maskuliinis-rationaalista logiikkaa. Kehon ja äänellisyyden nostaminen tekstipainotteisen rationaalisen merkityksenmuodostuksen rinnalle nostaa myös musiikin aidosti tasaveroiseen asemaan tekstin kanssa.

\section{Barthesilainen laulu käytännössä}

Alla annan vielä käytännön esimerkin, kuinka laulamalla esitetään sukupuolta ja kuinka barthesilainen laulaminen voisi toimia. Tarkoitan barthesilaisella laululla feno- ja genolaulun jatkumon hyödyntämistä laulamisen ajattelussa ja toteutuksessa. Tämän artikkelin puitteissa ei ole mahdollista antaa yksityiskohtaista selostusta, mutta toivon tämän tiivistetyn esimerkin valaisevan sitä, mitä olen yllä käsitellyt teoretisoinnin tasolla. Jätän pois tarkastelustani myös yhteistyön pianistin kanssa. Liedin esittäminen on kahden tasavertaisen muusikon yhteistyötä, mutta sen kuvaaminen ei valitettavasti mahdu tämän artikkelin piiriin.

Feno- ja genolaulu ovat läsnä kaikessa laulamisessa. Niiden tietoisella käytöllä laulaja voi toteuttaa omaa taiteellista näkemystään. Vaihtelemalla niiden painostusta laulaja voi vaikuttaa esimerkiksi sukupuolen esityksiin. Kiinnitän huomion esimerkkilaulun kohtiin, joissa feno- ja genolaulun välisten painotusten vaihtamisella on suuri merkitys soivan lopputuloksen ja sukupuolen esitysten kannalta. Esimerkkieni ja väitteideni perustana on kokemukseni ammattilaulajana. Kirjoitan laulusta omasta asemastani äitinä, valkoisena, cis-naiseksi identifioituvana, heteroseksuaalisena laulajana. Identifioitumiseni vaikuttaa tulkintaani laulusta ja rajaa mahdollisia sukupuoliperformansseja omassa esiintymisessäni, sillä kehoni on elämäni saatossa muokkautunut vastaamaan identiteettejäni eikä sukupuolen esittäminen ole kokonaan tietoinen prosessi (Butler 1993, 2). Luentani runosta on feministinen. Runo on mahdollista tulkita myös toisin, mutta sukupuolen esittämisen tarkastelemiseksi feministinen luenta on tarkoituksenmukainen. 
Brahmsin "Von ewiger Liebe" op. 43/1 on von Fallerslebenin tekstiin vuonna 1864 sävelletty ja vuonna 1869 julkaistu laulu. ${ }^{11}$ Se kuuluu keskeiseen lied-ohjelmistoon, ja sen on levyttänyt huomattava määrä laulajia Thomas Allenista Elisabeth Schwarzkopfiin. Runossa on kolme puhujaa: kertojaääni, poika ("Bursche") ja tyttö ("Mägdelein"). Laulajan on otettava kantaa siihen, kuinka esittää ne. Mikäli laulaja haluaa tehdä selkeät erot eri puhujien välillä, laulajan on siis ratkaistava osallistumisensa puhujien sukupuolittamiseen.

Brahms on sukupuolittanut tytön ja pojan säveltämällä pojalle mahtipontista, selkeärytmistä musiikkia ja nousevia, nopeaa harmonista liikettä sisältäviä fraaseja (ks. kuva 1). Tytön musiikki on loppuhuipennusta lukuun ottamatta dynamiikaltaan poikaa hiljaisempaa, 6/8-tahtilajissa keinahtelevaa ja harmoniselta liikkeeltään hitaampaa (ks. kuva 2). Laulu alkaa ajan ja paikan asettamisella kertojan äänellä, poikaa seuraten eli miesnäkökulmasta. Miesnäkökulma korostuu kertojan ja pojan sävellajin ja tahtilajin yhteneväisyydellä. Tytön puhuessa tahtilajin lisäksi sävellaji vaihtuu muunnosduuriin. Näin syntyy asettelu, jossa tyttöpuhuja toiseutetaan (mies)kertojaan ja poikapuhujaan nähden.

Kertojan miesnäkökulma tai -katse antaa ymmärtää, että myös tytön repliikki on samasta näkökulmasta, runon retorisen minän tyttöpuhujan suuhun asettamia sanoja. Tyttöpuhujan ääni ei näin siis olekaan tytön vaan (mies)kertojan rakentama. Mikäli laulaja ei aktiivisesti viesti muuta, laulaja asettuu subjektiksi mieskatseella luotuun heteronormatiivisuuteen ja sukupuolijärjestelmään, jossa nainen on olemassa maskuliinisen halun kohteena. Tyttöpuhujan ehdoton omistautuminen pojalle toistaa miestä varten elämisen ja miehen valtaan alistumisen narratiiveja. 1800-luvun yhteiskuntaan peilattuna tytön häpeään saattamisessa saattaisi olla kyse esimerkiksi tytön ja pojan välisestä luokkaerosta tai mahdollisesta avioliiton ulkopuolisesta raskaudesta.

Dunkel, wie dunkel in Wald und in Feld! Abend schon ist es, nun schweiget die Welt. Nirgend noch Licht und nirgend noch Rauch, Ja, und die Lerche sie schweiget nun auch.

Kommt aus dem Dorfe der Bursche heraus, Gibt das Geleit der Geliebten nach Haus,
Metsä ja vainio pimenneet ovat, On jo ilta ja maailma vaikenee. Missään ei valoa, ei savua näy, Ja kiurukin hiljenee.

Nuorukainen kylästä tulee, Saattamaan rakkaintaan kotiin,

${ }^{11}$ Perinteisen heteronormatiivisen tulkinnan laulusta antaa esim. Dunsby 2004. 
Führt sie am Weidengebüsche vorbei, Redet so viel und so mancherlei:

"Leidest du Schmach und betrübest du dich, Leidest du Schmach von andern um mich, Werde die Liebe getrennt so geschwind, Schnell, wie wir früher vereiniget sind. Scheide mit Regen und scheide mit Wind, Schnell wie wir früher vereiniget sind."

Spricht das Mägdelein, Mägdelein spricht: „Unsere Liebe sie trennet sich nicht! Fest ist der Stahl und das Eisen gar sehr, Unsere Liebe ist fester noch mehr. Eisen und Stahl, man schmiedet sie um, Unsere Liebe, wer wandelt sie um? Eisen und Stahl, sie können zergehn, Unsere Liebe muß ewig bestehn!"
Vie hänet viljavainion ohi, Puhuu kaikesta ja niin paljon:

”Jos tuskasta kärsit ja murehtia saat, Ja vuokseni sinua loukataan, Silloin rakkaus nopeasti haihtuu, Niin kuin se nopeasti yhteen vei. Lähde sateella, lähde tuulella, Nopeasti niin kuin yhteen menimme."

Ja neitonen vastaa ja sanoo: "Rakkautemme on erottamaton! Lujaa on teräs ja rautakin myös, Rakkautemme vahvempaa viel', Rautaa ja terästä takoa voi, Vaan rakkauttamme kuka muuttaa voi? Rauta ja teräs sulattaa voidaan, Vaan rakkautemme ikuinen on!'"12

Pojan ja tytön sukupuolittaminen laulajan tulokulmasta alkaa edellä esitetyn kaltaisella musiikin ja tekstin merkityksien pohtimisella. Minkälaisilla keinoilla säveltäjä ja runoilija ovat sukupuolittaneet runon puhujat? Voiko näitä keinoja korostaa jollain tavalla vai olisiko mielekkäämpää laulaa niitä vastaan? Minkälaisia sukupuoliperformansseja laulussa on? Laulajat pyrkivät usein erottamaan tekstin kolme puhujaa toisistaan. "Neutraalin" kertojaäänen vastakohtana on kovaa ja kiirehtien asiansa esittävä poika sekä pehmeän keinuvasti vastaava tyttö.

Laulaja voi korostaa pojan maskuliinisuutta esimerkiksi laulamalla peräkkäiset neljäsosat marcatona ("schnell wie wir früher...") ja vastata pianosatsin vasemman käden neljäsosien liikkeeseen. Tekstin osalta pojan maskuliinisuus korostuu kiinnittämällä huomio mahdollisen häpeän aiheuttajaan ja häpeän kohteeseen. Esiaviolliset suhteet ovat olleet perinteisesti nimenomaan tyttöjen häpeä, ja runon poikakin toivoo eroa vasta häpeän tapahduttua. Laulaja voi korostaa tätä nostamalla esiin etenkin häpeän, "Smach", ja sen aiheuttajan, "um mich". Pojan maskuliinisuus korostuu myös painottamalla nousevien fraasien loppuja, artikuloimalla konsonantit selkeästi ja rytmisesti sekä välttämällä diminuendoja ja käyttämällä tummaa äänenväriä. Muun muassa Fischer-Dieskau (2007) tekee juuri näin.

${ }^{12}$ Suom. Erkki Tammela. 

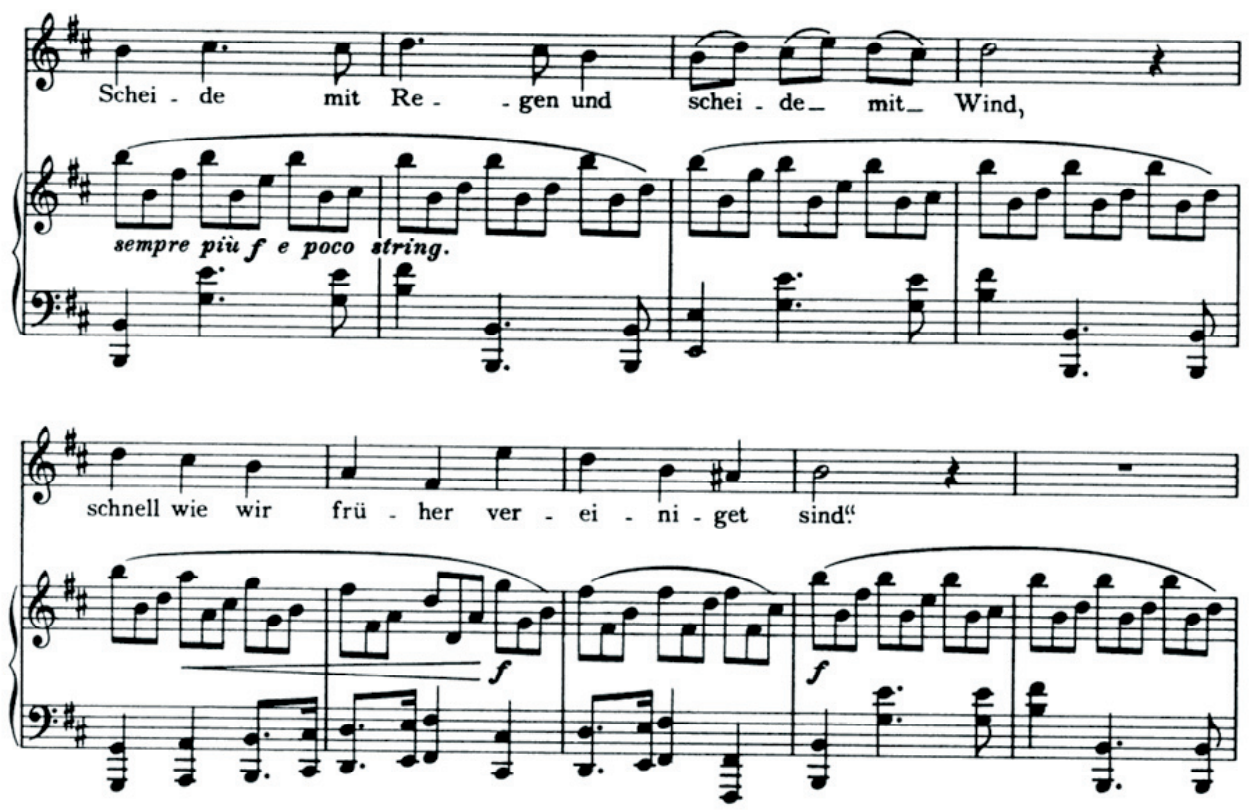

Kuva 1. Pojan musiikkia. Brahms: "Von ewiger Liebe", tahdit 61-69.

Tytön feminiinisyys on musiikin hitaassa harmonisessa liikkeessä ja keinuvassa rytmissä. Laulaja voi korostaa feminiinisyyttä aloittamalla fraasit pehmeästi ja alukkeetta. Sanojen "trennet" ja "wandelt" etuheleiden viettelevyyttä voi korostaa antamalla niiden nyrjäyttää keinuvaa pulssia pois paikaltaan. Etuheleiden laulaminen tempossa taas viestii tytön viattomuutta ja nuorta ikää, kuten esimerkiksi sopraano Anja Harteroksen tulkinnassa (2014). Feminiinisyys ja tytön nuori ikä korostuvat niin ikään äänenvärin vaaleudella ja tekemällä crescendot pienemmiksi kuin pojalla. Myös loppuhuipennuksen feminiinisyyttä voi tuoda esille laulamalla se ilman alukkeita ja tiiviissä legatossa kontrastina pojan marcato-rytmeille. Tekstin tasolla tyttö on omistautunut pojalle vakuuttaessaan heidän rakkautensa kestävyyttä. Huomioni kiinnittyy kuitenkin Brahmsin valintaan sijoittaa sana "fester" vähennetylle septimisoinnulle, joka dissonoivuudessaan on epävakaa ja ristiriidassa rakkauden kestävyyden viestiin nähden.

Loppuhuipennuksessa tytön 6/8-tahtilaji rikkoutuu pojan musiikista muistuttavalla kolmijakoisella iskutuksella (kuva 4). Yhteys Susan McClaryn (2002 [1991], 57) argumenttiin klassisen musiikin perinteen 
Ziemlich langsam
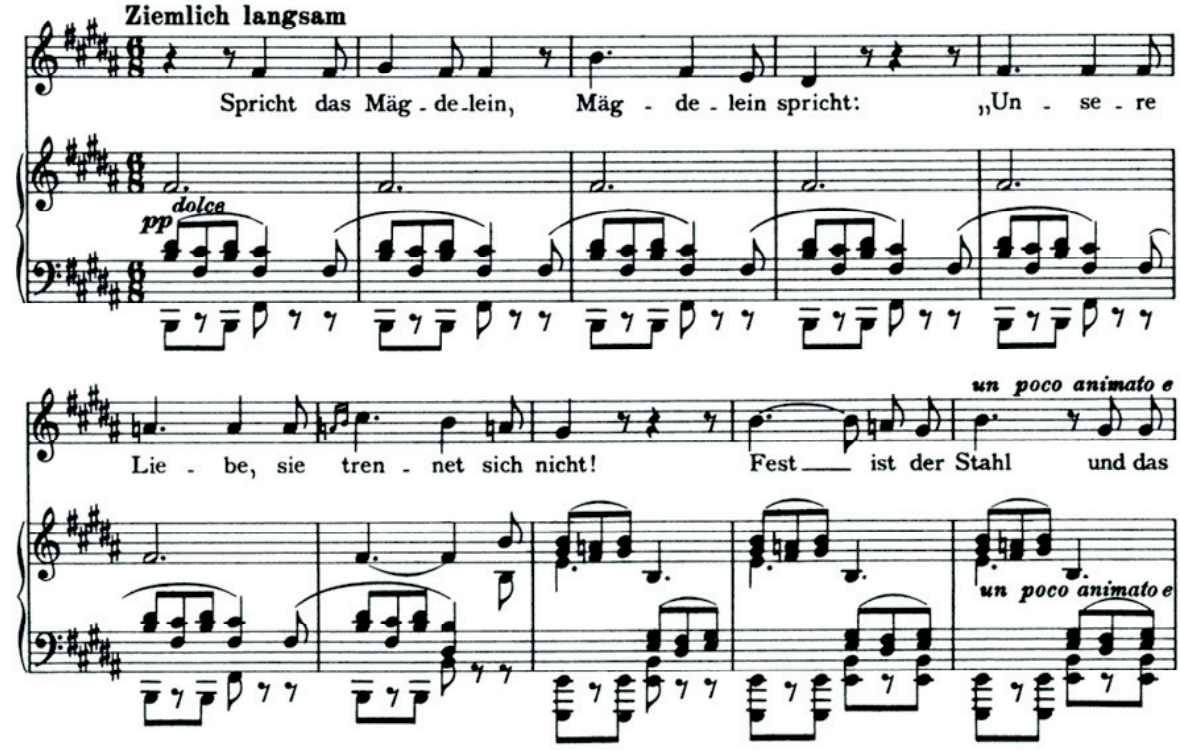

Kuva 2. Tytön musiikkia. Brahms: "Von ewiger Liebe", tahdit 79-88.
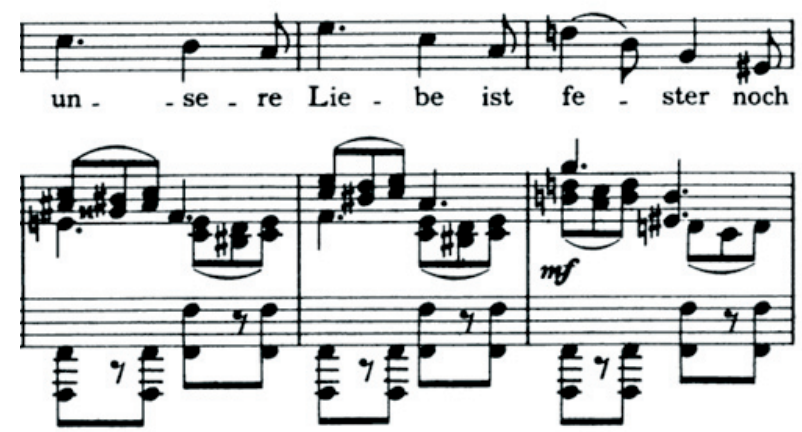

Kuva 3. Vähennetty septimisointu sanalla "fester". Brahms: "Von ewiger Liebe", tahdit 91-93.

asennoitumisesta kehollisuuteen on selkeä. Tytön musiikin keinahteleva rytmi viettelee kehoa liikkeeseen toisin kuin pojan musiikin tasainen pulssi. Keho ja ruumiillisuus ovat kuitenkin "korkeakulttuurin" piirissä alempiarvoisia transsendenttiin nähden, joten laulun lopun voi tulkita esimerkiksi tytön kohoamisena ruumiillisuuden yläpuolelle, tytön asettumisena maskuliinisen vallan alle tai yleisenä tarpeena tukahduttaa keho ja sen häiritsevät vietit. (Ibid.) 


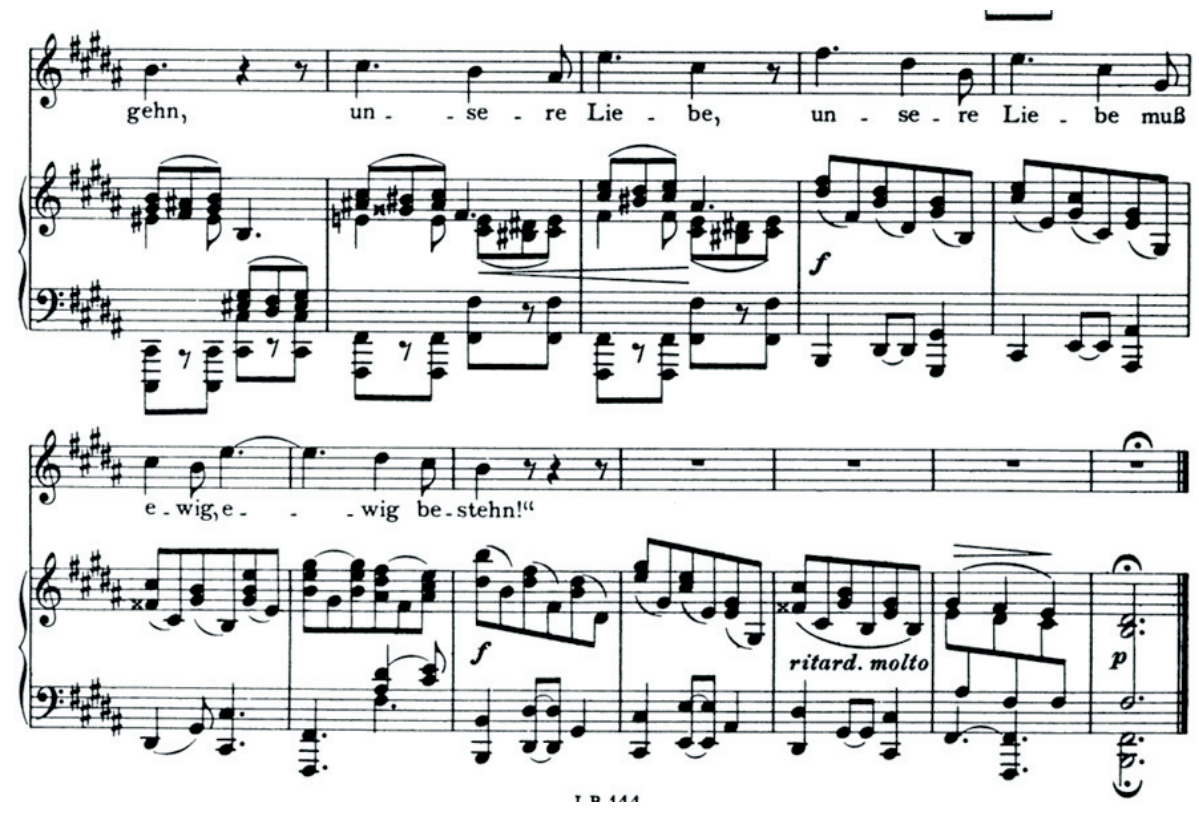

Kuva 4. Loppuhuipennus. Brahms: "Von ewiger Liebe”, tahdit 110-121.

Kaikki edellinen oli fenolaulua painottavaa ilmaisua. Mitä genolaulua kohti siirtyminen tarkoittaisi runon puhujien sukupuolittamisen kannalta? Pojan puhe sisältää paljon konsonantteja ja lyhyitä vokaaleja ("Schmach", "dich", "mich", "getrennt", "geschwind"). Niiden tuottaminen vaatii nopeaa liikettä artikulaatioon osallistuvilta lihaksilta. Liikkeen pysyminen vapaana taas vaatii artikulaation keveyttä. Omassa laulukokemuksessani poikapuhujan maskuliinisuus heikentyy, kun käännyn genolaulupainotukseen. Fraasit eivät enää tunnu tarkkarajaisilta, suunnatuilta palikoilta, vaan ne muuttuvat nestemäiseksi ja asettuvat orgaanisemmin kehooni. Tekstin fenolaulun keinoin 1800-luvulle lukitut merkitykset alkavat purkautua. Millä tavalla tai missä yhteydessä aikuinen, naiseksi sukupuolitetulla keholla ja äänellä laulava puhuja, joka on tekstissä sukupuolitettu maskuliiniseksi, voi tuottaa toiselle kärsimystä ja häpeää? Minkälainen on tällainen feminiinisen ja maskuliinisen rajat sekoittava ja ylittävä subjekti? Minkälaista kärsimys ja häpeä silloin on?

Genolaulua kohti kääntyminen korostaa runon tyttöpuhujan ruumiillisuutta. Huomioni kiinnittyy moniin pitkiin i- ja e-äänteisiin ("Liebe", "sie", "sehr", "mehr", "schmiedet", "zergehn", "ewig", "bestehn"). Niiden laulaminen vapaasti soivana vaatii ainakin itseltäni hienoista suun pyöris- 
tämistä suupielistä. Suun aistillinen pyöreä muoto alkaa jo tyttöpuhujan ensimmäistä äänteestä, joka on pisteellisen neljäsosan mittainen u ("unsere"). Vapaasti laulettu u-vokaali tuntuu suun pyöreyden lisäksi syvänä lantionpohjassa. Omassa laulukokemuksessani esiin nousee laulamisen ruumiillinen nautinto. Erityisen nautinnollinen on sana "Liebe" sävellajiin kuulumattomalla a-sävelellä, jonka voi lukea H-duurissa Toiseksi (ks. kuva 3). Kuunnellen kuvittelen myös altto Nathalie Stutzmannin (1997) nauttivan kyseisen sävelen laulamisesta. Aikuisen naisen keholla laulettu ruumiillinen nautinto, rakkaus ja toiseus tuottavat toisenlaisia assosiaatioita kuin fenolaulaen tuotettu tyttömäisyys ja kirkassilmäinen julistus ikuisesta rakkaudesta.

Nathalie Stutzmannin laulamana "Von ewiger Liebe" on täynnä viittauksia laulajan ruumiillisuuteen. Hän käyttää runsaasti portamentoja, vaihtelee suoran äänen ja vapaan vibraton välillä, päästää paikoitellen koko huomattavan äänensä valloilleen, laulaa väreilevää pianissimoa ja käsittelee rytmiä huolettoman vapaasti. Kaikki nämä pakottavat kuulijan kiinnittämään huomionsa tekstin sisältöjen ohella laulajan ääneen ja sen materiaalisuuteen. (Vrt. Välimäki 2005, 365.) Syntyy vaikutelma, jossa laulaja todella laulaa omana itsenään ja on ottanut tekstin osaksi omaa laulavaa kehoaan (vrt. Järviö 2011, 328). Naiseksi sukupuolitetun laulajan kehosta tulevana tekstin miesnäkökulma alkaa purkautua, sillä laulajan kehon sukupuolittuneisuus pakottaa kyseenalaistamaan miesnäkökulman. Toisaalta kitka tekstin ja kehon vuorovaikutuksessa kyseenalaistaa myös laulajan sukupuolittuneisuuden ja näin haastaa koko binäärisen sukupuolijärjestelmän. Stutzmann ei tyydy kuuliaisesti toistamaan nuottikuvan ja tekstin asettamaa normia, vaan queeriyttää sen asettamalla oman ruumiillisuutensa tulkinnan lähtökohdaksi.

Lauluääni on kehon esitys, jonka rajana ovat kehon rajat. Butlerin ajattelussa sukupuoli ei kuitenkaan ole biologian ennalta määrittämä, joten vastaavasti lauluäänikään ei todellisuudessa määrää sukupuolta, vaikka klassisen laulun kulttuurissa näin on (ks. Dame 2006 [1994], 140141). Butlerin ajattelu ja barthesilainen laulu purkavat tekstin merkitysten lisäksi myös äänityyppien sukupuolittuneisuutta, sillä kehon, äänen ja sukupuolen yhteys ei ole ennalta määrätty. Kun laulaja ei asetu tai halua asettua tekstin tarjoamiin ahtaisiin normeihin, keho on yksi tie ulos niistä. Koska genolaulu on saavuttamaton utopia, olen muokannut Barthesin ajattelua sopimaan laulajan käytäntöön. Laulaminen tapahtuu aina suhteessa yhteiskuntaan ja kulttuuriin, joten Barthesin romantisoitu ja sukupuoleton ajattelu laulajan kehon äänen kuulemisesta ei vastaa käytäntöä. 
Ruumiillisuuden kaihtaminen toistaa myös valkoisuuden normia (Bull 2019, 104). Barthesilainen laulu ja ruumiillisuuden esiin nostaminen purkavat sukupuolinormien lisäksi myös muita kehojen ominaisuuksiin, kuten ihonväriin liittyviä normeja ja merkityksiä. Kun ruumiillisuutta ei häivytä tekstin merkitysten välittämisen taakse, laulaminen näyttäytyy kaikenlaisille kehoille avoimena queerina tilana, jossa keho on aidosti mukana muodostamassa merkityksiä.

\section{Lopuksi}

Laulamisen kytkös feminiiniseen on kulttuurissamme vahva (ks. esim. Cavarero 2005 [2003]; Cusick 1999). Tähän artikkeliin liittyvän tutkimustyöni johdosta on vaikea olla ajattelematta, että liedin tekstin merkityksistä lähtevä esityskonventio maskuliinistaa laulamista. Tämän seurauksena laulaminen on muuttunut hyväksyttävämmäksi myös miehille. Cusick $(1999,33)$ esittää laulamisen olevan niin syvälle kehon rajojen sisäpuolelle ulottuvaa toimintaa, ettei se sovi kehon rajojen rikkomattomuutta vaalivaan maskuliinisuuteen. Lied-laulun kontekstissa tekstiä ja transsendenttia painottava konventio häivyttää laulukulttuurin lävistämää kehoa, ja merkityksiä määrittämällä se samalla vahvistaa laulavan subjektin rajat.

Tässä artikkelissa olen asettanut vastakkain saksalaisen fischer-dieskaulaisen lauluperinteen ja Barthesin lauluajattelun. Niiden avulla olen kuvannut saksalaisen lied-laulamisen kulttuuria ja sen suhdetta laulajien kehoihin ja ruumiillisuuteen. Luin ja kuuntelin Fischer-Dieskauta ja näin löysin monia myös omasta koulutuksestani ja ammatillisesta toiminnastani tuttuja asioita, kuten liikkeen kaihtamisen ja sanottavan ensisijaisuuden. Barthesin ajattelua olen esitellyt ja soveltanut laulajan käytännön työhön liittyvin osin. Butlerin ajattelua hyödynsin laulamisen sukupuolen esitysten pohtimisessa. Olen osoittanut, että barthesilainen laulu voi olla laulamisen tietoista ajattelua toisin. Se on mahdollinen työkalu laulajalle, joka taiteessaan on kiinnostunut ruumiillisuudesta ja merkitysten reunoista. Olen kuvannut käytännön esimerkin avulla, kuinka laulaja voi liikkua feno- ja genolaulun jatkumolla tuoden sukupuolinormittamista kaihtavan elementin laulamiseensa. Fischer-Dieskaun tavoin ajattelen, että valmistautuminen on tärkeä osa laulajan työtä. Olenkin painottanut laulajan taitoa ja tietoisia taiteellisia valintoja. Olen tässä artikkelissa esitellyt tavan, jolla laulaja voi kehonsa avulla rikastaa ilmaisuaan. Löysin 
barthesilaisesta laulusta queerin tilan, jossa sukupuolen ja seksuaalisuuden moninaisuus saa näkyä ja kuulua yhdenvertaisena. Kaikki ihmiset eivät mahdu normien sisälle, joten laulajienkaan ei tarvitse.

\section{Lähteet}

\section{Nuottijulkaisut}

Brahms, Johannes. 1926-27 [1857]. Von ewiger Liebe op. 43/1. Leipzig: Breitkopf und Härtel. Tark. 5.2.2021. https://imslp.org/wiki/4 Songs, Op.43 (Brahms, Johannes)

\section{Ä̈̈nitteet}

Fischer-Dieskau, Dietrich. 2007 [1952/1954].J. Brahms: Die schöne Magelone. Audite, ADD.

Harteros, Anja \& Wolfram Rieger. 2014. Von ewiger Liebe - Lieder. Berlin Classics 0300621BC.

Stutzmann, Nathalie \& Inger Södergren. 1997. Brahms: Lieder. RCA Red Seal.

\section{Videot}

Monsaingeon, Bruno. 1995. Dietrich Fischer-Dieskau. La voix de l'âme. Ideale Audience/Sender Freies Berlin/ Imalyre Group France Télécom/ La Sept Arte. Tark. 4.2.2021. https://youtu.be/W AeQxjq1B8

Fischer-Dieskau, Dietrich \& Alfred Brendel. 1979. Schubert: Winterreise. Tark. 4.2.2021. https://youtu.be/5PQtpc_5QH

Fischer-Dieskau, Dietrich \& Gerald Moore. Schubert: Erlkönig. Konserttitaltiointi 1960-luvulta. Tark. 4.2.2021. https://youtu.be/PaBNUzVSnj8

\section{Kirjallisuus}

Barthes, Roland. 1985a [1972]. "The Grain of the Voice". Teoksessa The Responsibility of Forms, käänt. Richard Howard, 267-277. Berkeley, CA: University of California Press.

Barthes, Roland. 1985b [1976]. "The Romantic Song”. Teoksessa The Responsibility of Forms, käänt. Richard Howard, 286-292. Berkeley, CA: University of California Press.

Barthes, Roland. 1994 [1968]. "La mort de l'Auteur". Teoksessa Le bruissement de la langue, 61-67. Paris: Éditions du Seuil.

Binder, Benjamin. 2020. "Song in Concert as Observed by the Schumanns. Toward the Personalization of the Public Stage". Teoksessa German Song Onstage: Lieder Performance in the Nineteenth and Early Twentieth Centuries, toim. N. Loges ja L. Tunbridge, 52-69. Bloomington, IN: Indiana University Press. https://doi.org/10.2307/j.ctv104t9zt 
Bonenfant, Yvon. 2010. "Queer Listening to Queer Vocal Timbres". Performance Research, 15 (3): 74-80. https://doi.org/10.1080/13528165.2010.527210

Borchard, Beatrix. 2020. "The Concert Hall as a Gender-Neutral Space. The Case of Amalie Joachim née Schneeweiss". Käänt. Jeremy Coleman. German Song Onstage: Lieder Performance in the Nineteenth and Early Twentieth Centuries, toim. N. Loges ja L. Tunbridge, 132-153. Bloomington, IN: Indiana University Press. https://doi.org/10.2307 i.ctv104t9zt

Brett, Philip, Elizabeth Wood ja Gary C. Thomas. 2006 [1994]. Queering the Pitch. London: Taylor \& Francis. https://doi.org/10.4324/9780203944189

Bull, Anna. 2019. Class, Control, and Classical Music. New York, NY: Oxford University Press. https://doi.org/10.1093/oso/9780190844356.001.0001.

Butler, Judith. 2006 [1990]. Gender Trouble: Feminism and the Subversion of Identity. New York, NY: Routledge. https://doi.org/10.4324/9780203824979

Butler, Judith. 1993. Bodies that Matter: On the Discursive Limits of "Sex". 1st ed. New York, NY: Routledge.

Cavarero, Adriana. 2005 [2003]. For More than One Voice. Toward a Philosophy of Vocal Expression. Käänt. Paul A. Kottman. Stanford, CA: Stanford University Press.

Cusick, Suzanne G. 1999. "On Musical Performances of Gender and Sex". Teoksessa Audible Traces. Gender, Identity, and Music, toim. E. Barkin ja L. Hamessley, 25-48. Zürich \& Los Angeles: Carciofoli.

Cusick, Suzanne G. 2006 [1994]. ”On a Lesbian Relationship with Music: A Serious Effort Not to Think Straight". Teoksessa Queering the Pitch, toim. Philip Brett et al., 67-84. New York, NY: Taylor \& Francis. https://doi.org/10.4324/9780203944189

Dame, Joke. 2006 [1994]. "Unveiled Voices. Sexual Difference and the Castrato". Teoksessa Queering the Pitch, toim. Philip Brett et al., 139-154. New York, NY: Taylor \& Francis. https://doi.org/10.4324/9780203944189

Dunsby, Jonathan. 2004. "A Love Song: Brahms's 'Von ewiger Liebe'”. Teoksessa Making Words Sing: Nineteenth- and Twentieth-Century Song, 33-56. Cambridge: Cambridge University Press.

Dunsby, Jonathan. 2009. "Roland Barthes and the Grain of Panzéra's Voice". Journal of the Royal Musical Association 134 (1): 113-132. Tark. 18.6.2021. https://www.jstor. org/stable/40783132

Fast, Susan ja Craig Jennex. 2019. Popular Music and the Politics of Hope: Queer and Feminist Interventions. New York, NY: Routledge. https://doi.org/10.4324/9781315165677.

Fischer-Dieskau, Dietrich. 1971. Auf den Spuren der Schubert-Lieder: Werden, Wesen, Wirkung. Wiesbaden: F. A. Brockhaus Verlag.

Fischer-Dieskau, Dietrich. 1981. Robert Schumann. Wort und Musik. Das Vokalwerk. Stuttgart: Deutsche Verlags-Anstalt.

Fischer-Dieskau, Dietrich. 1984. The Fischer-Dieskau Book of Lieder. Käänt. G. Bird ja R. Stokes. New York, NY: Limelight Editions.

Fischer-Dieskau, Dietrich. 1985. Töne sprechen, Worte klingen. Zur Geschichte und Interpretation des Gesangs. München: DVA/Piper.

Goehr, Lydia. 1998. The Quest for Voice. Music, Politics, and the Limits of Philosophy. Berkeley, CA: University of California Press.

Jagose, Annamarie. 1996. Queer Theory. An Introduction. New York, NY: New York University Press.

Jarman-Ivens, Freya. 2011. Queer Voices. Technologies, Vocalities, and the Musical Flaw. New York, NY: Palgrave Macmillan. http://dx.doi.org/10.1057/9780230119550

Järviö, Päivi. 2011. Laulajan sprezzatura: fenomenologinen tutkimus italialaisen varhaisbarokin laulaen puhumisesta. Helsinki: Suomen musiikkitieteellinen seura. Tark. 22.5.2021. http://urn.fi/URN:ISBN:978-951-98479-8-6 
Kauppala, Anne. 2020. "Barthes's 'The Grain of the Voice' Revisited”. The Routledge Handbook of Musical Signification, toim. Esti Sheinberg ja William P. Dougherty, 67-77. New York: Routledge.

Koestenbaum, Wayne. 1994. The Queen's Throat: Opera, Homosexuality, and The Mystery of Desire. New York, NY: Vintage Print.

Kramer, Lawrence. 1995. Classical Music and Postmodern Knowledge. Oakland, CA: University of California Press.

Kramer, Lawrence. 2011. "Sexing song: Brigitte Fassbaender's 'Winterreise"”. Teoksessa Word and Music Studies: Essays on Performativity and on Surveying the Field. WMS 12, 157-171. Leiden: Brill https://doi.org/10.1163/9789401207454 011

Leech-Wilkinson, Daniel. 2020. Challenging Performance: Classical Music Performance Norms and How to Escape Them. Version 12.02 (11.12.2020). https://challengingperformance.com/the-book,

McClary, Susan. 2002 [1991]. Feminine Endings: Music, Gender, and Sexuality. Minneapolis, MN: University of Minnesota Press.

Miller, Richard. 1999. Singing Schumann: An Interpretive Guide for Performers. New York, NY: Oxford University Press.

Peraino, Judith A. 2006. Listening to the Sirens: Musical Technologies of Queer Identity from Homer to Hedwig. Berkeley, CA: University of California Press. https://doi. org/10.1525/california/9780520215870.001.0001.

Petersen, Lise Helmer. 2001. "Aspekter af 'le Grain de la Voix' - stemmens krop". Caecilia 2001(1): 149-162. Tark. 22.5.2021. http://danishmusicologyonline.dk/arkiv/ arkiv_caecilia_pdf/cc_1998-2001/cc_1998-2001_04_AspekterLHP_ocr.pdf

Potter, John. 2006. "Beggar at the Door: The Rise and Fall of Portamento in Singing". Music E Letters 87 (4): 523-50. Tark. 18.6.2021. http://www.jstor.org/stable/4140308. https://doi.org/10.1093/ml/gcl079.

Potter, John ja Neill Sorrell. 2012. A History of Singing. Cambridge: Cambridge University Press. https://doi.org/10.1017/CBO9781139024419.

Reece, Tyler Michael-Anthony. 2019. Liebe und Leben: Exploring Gender Roles and Sexuality in Nineteenth-Century Lieder. Väitöskirja, University of California. Tark. 17.6.2021. https://escholarship.org/uc/item/90m3844k

Sivuoja-Gunaratnam, Anne. 2007. "Barthes, ääni-kieli ja musiikki". Teoksessa Vastarinta/ Resistanssi. Konfliktit, vastustus ja sota semiotiikan tutkimuskohteina, toim. Harri Veivo, 54-73. Helsinki: Yliopistopaino.

Tunbridge, Laura. 2010. The Song Cycle. Cambridge: Cambridge University Press.

Välimäki, Susanna. 2005. ”Musiikki, ruumis, ääni - ja k. d. lang. Filosofinen ja musiikkianalyyttinen vuoropuhelu". Teoksessa Musiikin filosofia ja estetiikka. Kirjoituksia taiteen ja populaarin merkityksistä, toim. Juha Torvinen ja Alfonso Padilla, 359-394. Helsinki: Yliopistopaino.

Välimäki, Susanna. 2015. Muutoksen musiikki. Pervoja ja ekologisia utopioita audiovisuaalisessa kulttuurissa. Tampere: Tampere University Press. Tark. 22.5.2021. http://urn. fi/URN:ISBN:978-951-44-9732-2

Wahlfors, Laura. 2013. Muusikon kumousliikkeet. Intiimin etiikkaa musiikin käytännöissä. Helsinki: Tutkijaliitto.

Youens, Susan. 2013 [1991]. Retracing a Winter's Journey: Franz Schubert's ”Winterreise". Ithaca, NY: Cornell University Press. 